\title{
A case study of ethical issue at Gucci in Shenzhen, China
}

\author{
Li Wang • Robin Stanley Snell
}

Received: 27 February 2012 / Accepted: 25 September 2012 /Published online: 9 October 2012

(C) Springer Science+Business Media Dordrecht 2012

\section{Introduction}

Gucci is a multinational company with over 270 directly operated stores worldwide, serving customers of elite goods, and generating billions of dollars revenue per year. It has an iconic, even noble, luxury brand image in the Greater China region, where its revenue increased by $35.6 \%$ in the first half of year 2011 . Gucci has expressed its intention to accelerate the process of opening stores on the Chinese mainland. Recently, however, the company came under fire after five former employees from its flagship store in Shenzhen revealed information online about inhumane working conditions and labor mistreatment in the company. This paper focuses on events that took place in a Gucci flagship store located in Shenzhen, China.

This paper has two main research objectives. The first is to analyze why labor abuses (as exemplified in the Gucci case) are allowed to occur and persist in foreigninvested firms that are located in the People's Republic of China (PRC). The second is to develop a multi-stakeholder approach to preventing further abuses of this kind. The next section provides a description of the case, focusing on the ethically problematic labor management practices and arrangements and noting some legal violations. We shall then present three propositions regarding why some foreign firms operating in the PRC and host local governments ignore and/or tolerate labor abuses of this kind. We follow this with a section in which we apply two different approaches, traditional Confucian ethics on the one hand and modern labor rights

\footnotetext{
L. Wang $(\bowtie)$

Lingnan University, 12D, Block B, Chong Yip Center, Whitty Street, Hong Kong Island, Hong Kong e-mail: bestlillianwang@gmail.com

L. Wang

e-mail: liwang@ln.hk

R. S. Snell

Lingnan University, Room 209/3, 2/F, Simon and Eleanor Kwok Building, 8 Castle Peak Road, Tuen Mun, Hong Kong

e-mail: robin@ln.edu.hk
} 
theory on the other, to provide a robust ethical basis for stakeholders to argue from, while taking action to persuade others that such malpractices are ethically unacceptable. Next, after identifying four stakeholders for the Gucci case, we suggest how each of them may play a role in discontinuing and/or preventing future labor abuses. We conclude with some further theoretical and managerial implications.

\section{Case description}

The employees' complaints

On 8 October 2011, an open letter $<<$ A Public Letter to the Top Management of Gucci from Former Employees who resigned collectively> was spread on the Internet. This letter was written by five former employees of the Gucci Shenzhen Flagship Store. In the letter, they alleged that employees caught an occupational disease, that there was one miscarriage attributable to excessive working hours and that there was no compensation for these hardships. Moreover, they stated that there were excessive restrictions on employees' behavior, including the need to obtain permission before getting a drink or a snack, and strict limitations on toilet time. They stated that, while the restrictions were applied strictly to all frontline employees, including one who was pregnant, they were not applied to the managers. The letter also claimed that the employees had to pay compensation for any product that was stolen or went missing, even though these luxury products had already been insured. They also criticized Gucci's goods exchange policies which appeared to be arbitrary and dependent on the manager's mood. All in all, they accused Gucci of lacking systematic and humane management and complained that their rights and dignity were being violated.

Once revealed online, this report aroused widespread discussion among Internet users. Further information emerged, suggesting that the case also involved falsification of records about working hours, and the imposition of forced, unpaid overtime work. Gucci implemented a system of working one full day, followed by a day off. Officially, 1 day's work was about $10 \mathrm{~h}$. But the workers complained that, on their working days, they were required to clock off at a certain time to establish a false electronic record, and then continue their work, counting goods until two or three o'clock in the morning without compensation.

Some netizens labeled Gucci as a "sweatshop." Many opined that the labor management practices of some multinational companies and brand owners failed to match their international status. Several days later, the Gucci headquarters in China issued a statement, saying that "Gucci does not and will not endorse or tolerate the alleged malpractices." Gucci also stated that that the company had conducted thorough investigations and had implemented a series of measures, including the replacement of the store manager and assistant store manager. Meanwhile, the Human Resources Bureau within the Legal Department of Shenzhen's Luohu District said they would further investigate the case. On 26 October 2011, Gucci and the former employees eventually arrived at a settlement in conjunction with Shenzhen Federation of Trade Unions. 
How Gucci used the labor dispatch system

Dispatch is a labor management model which separates recruitment from employment. Relationships under the dispatch system are portrayed in Fig. 1. The employee leasing companies have labor contracts with the workers, and they send workers to other companies in which these workers actually work. The labor contract relationship exists between the employee leasing companies and the dispatched workers, but the actual working relationship is between the workers and the companies in which they work.

In this form of employment, the company which actually "use" these workers is only responsible for paying wages, while other aspects, including social security and dismissal compensation are passed on to the employee leasing company. The labor dispatch arrangement serves to reduce the user companies' costs and contractual responsibilities for the employee. They can incur lower training costs and are not required to make social security arrangements. Because of these features, this employment model is widely used in China. The Gucci stores in Shenzhen actually adopted an even more complex dispatch system, involving at least three employee leasing companies that were located in Shanghai.

\section{Legal considerations}

One legal consideration is that, although the labor dispatch system has been officially adopted as way of arranging temporary employment only, Gucci used the system to employ people for durations of more than 2 years. Another is that many of the Gucci store employees are female and that pregnant employees legally enjoy special labor protection. According to the "Labor Contract Law," female workers during their pregnancy should not participate in the state's third-grade physical intensive work. Such work is deemed not suitable for female workers; for female workers who are more than 7 months pregnant, there should be no overtime work, and they should not be required to join night shifts. Furthermore, it is a legal requirement that sufficient rest periods should be arranged for such employees.

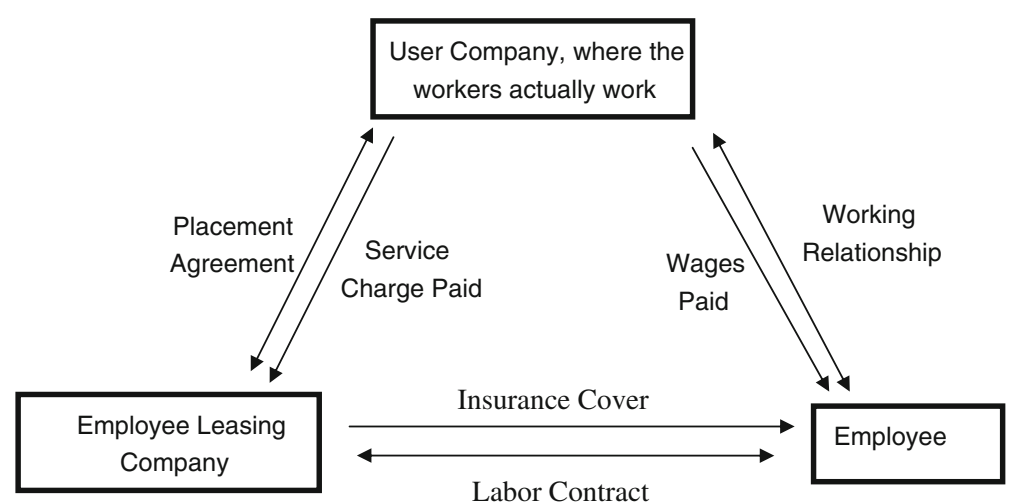

Fig. 1 Relationships under the dispatch system 


\section{Why do labor abuses happen in China?}

Underpinning the legal considerations, the basic ethical issue in this case is the violation of labor rights, through non-remunerated and forced work, inhuman restrictions, and other unreasonable policies. Gucci is by no means the first multinational company that has been accused of operating a "sweatshop" in Asia. For example, Nike was involved in abusive practices in Indonesia (Krueger 2007). What is especially interesting about this case is that it involves retail employees rather than factory workers. Also notable is that such labor abuses are generally uncommon in the Western countries, where these multinational corporations (MNCs) are quartered. Why did they come to China and "collectively fall ill"? We envisage that there are three possible reasons: First, overtime work without payment and other illegal employment arrangements are tolerated among local firms, and when foreign brands and multinational companies come to China, it is an easy temptation for them to slide into these malpractices, while giving themselves the excuse that it is a way of "adapting to the environment" (Hofstede 1993), i.e., moral relativism. Hence,

Proposition One: A philosophy of moral relativism allows some foreign firms in China to level down to abusive but locally condoned labor management practices.

The second possible reason for the persistence of labor abuses in China involving MNCs is that these large companies do not pay attention to the labor laws, let alone lobby to strengthen the laws and their enforcement, because they think their investment will furnish the local government with a good-looking GDP and that this is all that matters to them. Hence,

Proposition Two: Some foreign firms in China are preoccupied with economic goals, assume that local governments share their preoccupation, and believe that, because of shared economic imperatives, they can ignore the labor laws with impunity (Gao 2009; Ip 2009; McDonald 1995).

The third reason is closely related to the second one and concerns how the pressures faced by local governments are reflected in their actual preoccupations. Despite movement toward the balancing of economic imperatives with social and environmental concerns under the "Harmonious Society" policy platform (See 2009), local governments still remain under pressure to meet economic targets. Although there is a considerable body of labor laws in the PRC, officials may perceive there is little risk of being punished if it is discovered that they have failed to enforce them. Furthermore, some local governments may be afraid that the strict implementation of the labor law will drive investors away and may consciously turn a blind eye to illegal and unethical practices by firms under their purview, resulting in lax monitoring and non-enforcement.

Proposition Three: Because some local governments perceive that economic imperatives override social responsibility concerns, they are lax in enforcing labor laws. 


\section{Two perspectives-how can we tell right from wrong?}

We shall draw on two very different perspectives to conduct a moral evaluation of the labor management practices in the Gucci case. The first perspective is that of traditional Confucian ethics, the second is modern labor rights theory.

\section{Confucianism}

The core of Confucian ethics is comprised of five values. We shall focus on three of them-Ren, Yi, and Li. Ren is a capacity for compassion or benevolence for fellow humans. It is essentially expressed in social relationships. One can have a harmonious relationship with others and thinking about others' stakes when doing business draws on Ren (Wang and Juslin 2009). In effect, Ren expresses the Confucian formulation of the Golden Rule: People should not do to others things that they do not want others to do to them. Consideration for others, caring for others, and loving others means Ren. By contrast, in the Gucci case, the management operates only with the economic interest of company in mind, with no regard for workers' basic needs. It abused the dispatch system for the sole purpose of lowering the cost of hiring people, without considering workers' needs for adequate salaries, social insurance, training ... etc, thereby failing to practice Ren.

Of equal importance in Confucian ethics is $\mathrm{Yi}$, which concerns the morality of righteousness. It is the capacity to discern appropriateness and the right direction for actions, relationships, and other human matters. Helping people when they are in need is one expression of Yi, but in the Gucci case, Yi is absent. For example, the employee who was pregnant should have been treated with special care, and help should have been given to her when she needed it, but to the contrary, long working hours and strict working restrictions led to her miscarriage.

Third, Confucian morality is regulated by Li, or decorum. This consists of a body of norms, rites, and unwritten understandings that govern and regulate social action in every aspect of daily endeavor (Lau 1992). Respecting people and their dignity involves $\mathrm{Li}$, but according to the employees' allegations, the management did not respect their dignity. Subject to many unreasonable restrictions, they were treated as if they were mere instruments to make money, rather than as human beings with dignity, and did not receive due respect and appropriate treatment.

A related aspect of Confucianism concerns the respective duties of the parties in a dyadic relationship. The junior party has the obligation to serve and obey the senior party, and the senior party has the responsibility to teach, lead, and look after the junior party. Applied to modern employment relationships, this would entail a benign arrangement under which the employees would be recognized and cherished as a key stakeholder group of the company, with which the company would build and maintain a cooperative relationship and seek win-win outcomes. "Squeezing" rather than nurturing employees may save economic costs and lead to more profits in the short-term, but, as in this particular case, is likely to give rise to low morale among employees and may lead to emotional distress and physical harm. The long-term risks include that employees will make their grievances public and that the company's reputation will be harmed as a result. 


\section{Labor rights}

In the advanced Western economies, the moral basis of human rights has been incorporated into legal rights. There are strong and well-enforced government laws and regulations and established labor to advocate and negotiate on behalf of workers; well-developed nongovernmental organizations (NGOs) and independent media make problems transparent and advocate remedies. There are also high levels of citizenship education. Worker rights and protections have thus been institutionalized within a system of law and democratic political accountability, and are monitored by unions, NGOs, and educators. Through these processes, public expectations of the ethical behavior of corporations have become progressively stricter; cases of labor abuse still occur but appear to be relatively uncommon rather than endemic (Greenwood 2012).

In China, however, labor rights turn out not be widely institutionalized and legal rights turn out not to be strongly enforced, allowing employers as the stronger party to exploit the employees as the weaker party. While there are differences between Western countries and China, all people in the world share the need for some basic characteristics of human dignity that ought never to be violated, regardless of social context (e.g., whether one lives in a rich or poor society) and thus regardless of whether they have an abundance of employment choices or nearly none, or whether they have adequate institutional mechanisms to protect their interests.

It is ethically insufficient for corporations merely to "do in Rome as Romans do." Expedient moral relativism should be replaced by broader and "thicker" moral norms that have universal application. The Universal Declaration of Human Rights Article 5 states that "No one shall be subjected to torture or to cruel, inhuman or degrading treatment or punishment." And Article 23 section (3) states that "Everyone who works has the right to just and favorable remuneration ensuring for himself and his family an existence worthy of human dignity, and supplemented, if necessary, by other means of social protection." The practices adopted by the management of Gucci in Shenzhen appear to have violated the Universal Declaration of Human Rights.

\section{Stakeholders and their relevant stakes}

To prevent the further occurrence of abusive practices in labor management requires efforts from various groups. In working out who needs to do what, we first need to define who the relevant stakeholders are (Argandona 1998). According to Freeman (1998), the stakeholders are defined as "any group or individual who can affect or is affected by the achievement of the firm's objectives." That is, we need to identify which groups can be affected by these abuses and which groups can prevent them (Carson 1993; Maak and Pless 2006). Stakeholders include the following.

1. The company and its shareholders, whose stake is that the company's reputation should be rebuilt. This scandal may disrupt Gucci's expansion plans in China, so the company has a strong incentive to take positive action repair the harm to its reputation there.

2. Employees: Regardless of whether an employee has resigned or still remains in employment with Gucci, he or she will require apologies and appropriate 
compensation. In addition, the current employees are likely to desire the adoption of more systematic management methods and improved working conditions.

3. Chinese government: It is the Chinese government's responsibility to ensure that worker's rights are enforced, especially on its own territory and that companies operate in accordance with the laws there.

4. Foreign (home) governments: Foreign governments have a stake in every firm that is headquartered in their territory, including those with subsidies in overseas countries, such as China. They can take action to reduce the incidence of labor abuses in China by enacting laws that are similar to the anti-bribery treaties that have been passed in many countries (OECD 2001).

\section{Possible solutions}

1. Action coordinated by Gucci: One means for a solution is for Gucci to lead efforts in developing and implementing industry-wide and worldwide codes of ethics, thereby creating a comprehensive set of explicit norms and expectation about ethical standards. This code should apply to all branches and stores in both developed and less developed countries (Beschorner and Müller 2007). Such codes have been successfully implemented by industries such as toys, textiles, and electronics. Those kinds of products are sold to mass markets. It is something of a paradox that Gucci, which sells a high-end product, has provided a poor working environment in China; surely a company like this is even more subject to public scrutiny and now under public pressure to adopt higher standards. We do not wish to imply that employees in mass market industries should be treated any worse, but one may expecte high-end providers to exert stronger ethical leadership worldwide in improving labor standards. The code should require every branch and stores of companies in the luxury industry to embrace ethical principles and embed them into management systems and policies and internal review processes.

Informed by common areas of worker rights identified in the literature on international labor management ethics, this code could include items on the following: use of written employment contracts with all workers, avoiding abuse of the dispatch system, equal pay for work of equal value, prohibition of compulsory and unpaid work, adherence to laws and regulations on working hours, provision of wages and benefits not below minimum legal requirements, anti-discrimination, antiharassment, anti-abuse, and respect for occupational health and safety.

In addition, the establishment of a socially responsible management systems should include a statement of social responsibility objectives and targets, along with sufficient human and financial resources to ensure that these objects and targets are clearly communicated, that the system is adequately implemented, and that there are mechanisms for regular monitoring and auditing of the system and for corrective action in the event of shortfalls (Carroll 1991; Carroll and Horton 1994; Gond et al. 2011).

Simply implementing an industry code is not enough. The headquarters of Gucci, Italy, should urge and encourage its branches in China to comply with the necessary 
ethical standards in China (and every other host country). The encouragement needs to be strong, because managements in China may seek excuses and claim that there would be inordinate financial costs, or that the code may be difficult to implement because of cultural barriers. The headquarters may arrange for auditing by independent third parties, such as NGOs. Otherwise the enforcement might be weak or nonexistent.

2. Action by employees: "Tolerance" is deeply rooted in Chinese people's thoughts, and most of the time, it is even considered as a virtue (in contrast to assertiveness). In this case, we may notice that employees were tolerant of abusive practices until severe harm actually happened (the female employee's miscarriage). The Chinese workers' awareness of their rights may have been weak, and they appear to be accustomed to enduring their unjust treatment, which perpetuates the abusive practices. As China's capitalism has been rapidly evolving, the institutional arrangements involved in human resource management, such as the labor dispatch system, have become increasingly complex and subject to abuse. In order to protect employees, it is of utmost importance to challenge the mindset of tolerance and to equip employees with a strong awareness of rights and of suitable ways to protect themselves collectively. They should be encouraged to get together and make their voice heard (like writing a public letter on the Internet). By voicing their grievances, they can attract more attention, thus win more support, and the relevant government departments are more likely to investigate into their concerns. Furthermore, they could express their hope to form organizations which have similar functions to those of independent trade unions in western countries, thereby helping them gain bargaining power vis-àvis employers (Preuss et al. 2009).

3. Action by the Chinese government: It is recommended that the Chinese government should revise its entire approach to the monitoring and regulation of labor rights. "Harmonious Society" pronouncements have been a step in the right direction (See 2009), but there is much further to go. Workers in China are under-protected because there are few organizations that workers can appeal to, and trade unions in China do not serve the same purpose as in Western countries. It's difficult for workers to stand up for themselves when their rights are at stake. In Western countries, companies are under the scrutiny of various NGOs and trade unions; these organizations protect workers' labor rights through collective bargaining power. On the surface, this is paralleled in China by The Constitution of the People's Republic of China, which requires that all its citizens have the rights of freedom of speech, freedom of the press, and freedom to peaceably assemble, organize, demonstrate, and petition. However, in practice, in order to organize in mainland China (i.e., to establish an NGO), one has to register the organization according to the Social Organizations Registration and Administration Act. If the organization does not do this, it is not protected under the law. It is criminal for such an organization to publicly accept outside donations without a legal status. In addition, to establish such an NGO, they must have a regular business location, full-time staff, a registration capital of more than thirty thousand yuan and official documents with a stamp of approval from the governmental agencies, which have been designated as "supervising offices." This 
complex and time-consuming process makes it virtually impossible to form a NGO in China unless the government is prepared to champion and support the process. Another barrier is that every non-governmental organization will be coadministered by a civil affairs governmental office. This unique "Chinese way" of double administration weakens the independence of an NGO. Nonetheless, the Chinese government could consider having experiments in certain industries. China is now the biggest luxury-product-consuming country, as well as the biggest luxury-product-manufacturing country, so it has both the biggest customer group and labor force of the luxury industry worldwide. The Chinese government should consider giving permission to set up such a nongovernmental organization with independent powers, to monitor these luxury multinational companies' operations in China.

4. Action by foreign governments: A foreign government is typically responsible for creating and enforcing laws that apply to all the companies operating in their country, including MNCs that are operating subsidiaries all around the world, including China. A Western country could simply enact a law requiring all companies to apply fair and decent labor standards worldwide. The detail of such legislation is of course a much more complex matter that we can discuss in this article. The basic idea is that, if a company violates labor standards in China, it could then be prosecuted in the home country by the respective Western government. This arrangement might be championed by supra-national bodies, such as the United Nations, but again, we do not have space in this article in detail of the legislation process; it would help greatly if there is close collaboration between the Chinese government, Western countries, and supra-national bodies.

\section{Theoretical and managerial implications}

There are some key theoretical and managerial implications of this case. The first of these concerns the limitations and possible distortions of the virtue-based approach to business ethics as it has been applied in China. While some managers may recognize that a virtue-based Confucian firm should seek harmony by expressing benevolence to its employees, who would reciprocate with loyalty and gratitude, some key aspects of this approach can be forgotten when facing modern economic pressures. What may be remembered by managements is that Confucian ethics is based on the premise of inequality between the senior and junior parties in the relationship and that the junior party is expected to go along with whatever treatment they receive without direct protestation. What may be forgotten by managements is that all this is premised on the assumption that the senior party should consider, respect, and be responsive to the needs of the junior party. Such empathic concern is unlikely to flourish without a channel for listening and without a powerful incentive to listen. In their absence, allpowerful managements become de-sensitized from the concerns of their employees, and labor abuses will ensue.

From this, a second implication can be inferred. In order to prevent labor abuses in the PRC, it is necessary to institute strong, legally based mechanisms for enforcing and protecting labor rights. Conveying legitimate bargaining rights to labor 
organizations that correspond to their independent trade union counterparts in the West is one key step in this process. The second key step is for the national and local governments in the PRC to join hands in assigning a higher priority to encouraging and supporting corporate social responsibility, no longer relegating this to an afterthought or empty, token slogan. This, in turn, implies a role for foreign firms and foreign governments. Strengthening legal safeguards for labor rights in Chinese organizations is likely to require cross-national dialogues within corporations and between foreign governments and the government of the PRC.

Does this need for legal underpinning imply that the Confucian cultural legacy has no role to play in underpinning labor rights and preventing labor abuses in the PRC? Actually, this is not the case. Although concern about the Confucian virtues appear insufficient to constitute a safeguard against ethical violations in China-based firms, the picture may be radically transformed if legal imperatives are introduced that would serve to remind managements about the need to listen, understand, and respond to the needs of their employees. Confucian values originated in ancient times, when "rule of man" prevailed and when modern rule of law was inconceivable. China, having rapidly and breathtakingly developed into a modern society within the last two decades, is probably ready now to undergo the truly revolutionary process of blending Confucian morality and the Western rights-based paradigm into a moral compass that is more suitable for the contemporary world (Snell 2001).

\section{Conclusions}

Allegations of abusive labor practices in MNCs are by no means new phenomena but have typically referred to manufacturing sites in less developed countries. This paper highlights a less-extensively documented phenomenon, featuring abuses happening at a retail store-Gucci's Shenzhen flagship store. Specifically, Gucci abused the dispatch system, which is a labor system with Chinese characteristics, and neglected some key labor rights. In considering how an MNC can operate ethically in China, we have considered some universal interpretations of labor rights, while taking account of Confucianism and the One-Party state, which are foundational components of China's culture and institutional framework (Liou 2010). We have made recommendations for action by MNCs and other stakeholders, namely, employees, the Chinese government, and even foreign governments, where these can exert legal influence over MNCs that are headquartered in their jurisdictions. We have also foreshadowed the possibility, in the near future, of a fusion between Confucian virtue ethics and Western rational-legal approaches to the assertion and protection of labor rights and the profound practical and theoretical implications that would ensue.

\section{References}

Argandona, A. (1998). The stakeholder theory and the common good. Journal of Business Ethics, 17, 1093-1102.

Beschorner, T., \& Müller, M. (2007). Social standards: toward an active ethical involvement of businesses in developing countries. Journal of Business Ethics, 73, 11-20. 
Carroll, A. B. (1991). The pyramid of corporate social responsibility: Toward the moral management of organizational stakeholders. Business Horizons, 34, 39-48.

Carroll, A. B., \& Horton, G. T. (1994). Do joint corporate social responsibility programs work? Business and Society Review, 90, 24-28.

Carson, T. L. (1993). Does the stakeholder theory constitute a new kind of social responsibility? Business Ethics Quarterly, 3, 171-176.

Freeman, R. E. (1998). A stakeholder theory of the modern corporation. In L. P. Hartman (Ed.), Perspectives in business ethics (pp. 171-181). Chicago: McGraw-Hill.

Gao, Y. (2009). Corporate social performance in China: Evidence from large companies. Journal of Business Ethics, 89, 23-35.

Gond, J.-P., Igalens, J., Swaen, V., \& Akremi, A. E. (2011). The human resources contribution to responsible leadership: An exploration of the CSR-HR interface. Journal of Business Ethics, 98, $115-132$

Greenwood, M. (2012). Ethical analyses of HRM: A review and research agenda. Journal of Business Ethics, pre-published online before print, 24 May, 2012, doi:10.1007/s10551-012-1354-y.

Hofstede, G. (1993). Cultural constraints in management theories. The Academy of Management Executive, 7, 81-94.

Ip, P. K. (2009). The challenge of developing a business ethics in China. Journal of Business Ethics, 88 (Supplement 1), 211-224.

Krueger, D. A. (2007). The ethics of global supply chains in China-Convergences of East and West. Journal of Business Ethics, 79, 113-120.

Lau, D. C. (1992). Confucius: The analects. Translation, HK: Chinese University Press.

Liou, K. T. (2010). Government-business relations in Greater China and challenges for public administration. Paper presented at the symposium on Reform and Transition in Public Administration Theory and Practice in Greater China, 1978-2008, University of Hong Kong.

Maak, T., \& Pless, N. M. (2006). Responsible leadership in a stakeholder society. A relational perspective. Journal of Business Ethics, 66, 99-115.

McDonald, G. (1995). Business ethics in China. In H. Davies (Ed.), China business: Context and issue (pp. 170-187). Hong Kong: Longman.

Organization for Economic Cooperation and Development. (2001). OECD convention on combating bribery of foreign public officials in international business transactions. Paris: OECD.

Preuss, L., Haunschild, A., \& Matten, D. (2009). The rise of CSR: Implications for HRM and employee representation. International Journal of Human Resource Management, 20, 953-973.

See, G. K. H. (2009). Harmonious society and Chinese CSR: Is there really a link? Journal of Business Ethics, 89, 1-22.

Snell, R. S. (2001). Moral foundations of the learning organization. Human Relations, 54, 319-342.

Wang, L., \& Juslin, H. (2009). The impact of Chinese culture on corporate social responsibility: The harmony approach. Journal of Business Ethics, 88, 433-451. 